\title{
Efficiency of rumen microbial protein synthesis in cattle grazing tropical pastures as estimated by a novel technique
}

\author{
M. K. Bowen ${ }^{\mathrm{A}, \mathrm{C}, \mathrm{D}}$, D. P. Poppi ${ }^{\mathrm{A}}$ and S. R. McLennan ${ }^{\mathrm{B}}$

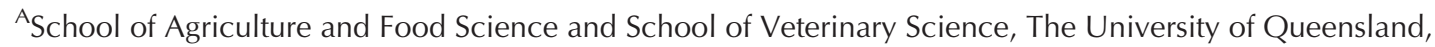 \\ Gatton, Qld 4343, Australia. \\ ${ }^{B}$ The University of Queensland, Centre for Animal Science, Queensland Alliance for Agriculture and Food \\ Innovation, Brisbane, Qld 4105, Australia. \\ CPresent address: Department of Agriculture and Fisheries, Rockhampton, Qld 4701, Australia. \\ ${ }^{D}$ Corresponding author. Email: maree.bowen@daf.qld.gov.au
}

\begin{abstract}
The efficiency of microbial protein synthesis (EMPS) in cattle grazing a range of tropical pasture types was examined using a new method of intra-jugular infusion of chromium-EDTA to estimate urinary excretion of purine derivatives. Seven pasture types were studied in south-eastern Queensland, Australia, over a 13-month period. These included native tropical grass $\left(\mathrm{C}_{4}\right)$ pasture (major species Heteropogon contortus and Bothriochloa bladhii) studied in the early wet, the wet-dry transition and the dry season; introduced tropical grass $\left(\mathrm{C}_{4}\right)$ pasture (Bothriochloa insculpta) in the mid-wet season; two introduced tropical legume species $\left(\mathrm{C}_{3}\right.$; Lablab purpureus and Clitoria ternatea $)$; and the temperategrass $\left(\mathrm{C}_{3}\right)$ pasture, ryegrass (Lolium multiflorum). There was a large range in EMPS across pasture types, with a range of 26-209 g microbial crude protein per kilogram digestible organic matter intake (DOMI). Estimated rumen-degradable protein (RDP) supply (42-525 g/kg DOMI) was the major factor associated with EMPS across the range of pasture types studied. EMPS in steers grazing all tropical grass pastures was low $(<130 \mathrm{~g} / \mathrm{kg}$ DOMI $)$ and limited by RDP supply. Negative linear relationships $(P<0.05)$ between EMPS and concentrations of both neutral detergent fibre and acid detergent fibre in extrusa were evident. However, non-fibre carbohydrate in extrusa, total non-structural carbohydrate concentration in plucked pasture leaf, rumen fluid and particle dilution rate, protozoal concentration in rumen fluid and rumen fluid $\mathrm{pH}$ were not correlated with EMPS. It was concluded that EMPS was well below $130 \mathrm{~g}$ microbial crude protein per kilogram DOMI when cattle grazed unfertilised, tropical grass pastures in south-eastern Queensland and that RDP was the primary limiting nutrient. High EMPS was associated with a very high RDP, vastly in excess of RDP requirements by microbes.
\end{abstract}

Additional keywords: rumen-degradable protein, urinary purine derivatives.

Received 2 September 2015, accepted 11 April 2016, published online 19 August 2016

\section{Introduction}

Microbial crude protein (MCP) usually provides the majority of the total protein supply to ruminants grazing tropical pastures (CSIRO 2007). The various feeding standards give an average value or range for the efficiency of microbial protein synthesis (EMPS) in the rumen in relation to energy availability. The expected range of EMPS values proposed in the feeding standards for diets other than silage is $130-170 \mathrm{~g} \mathrm{MCP} / \mathrm{kg}$ digestible organic-matter intake (DOMI; AFRC 1993; CSIRO 2007). The feeding standards recognise that EMPS is not a constant but may vary according to diet type, with adjustments recommended for stage of maturity and type of pasture (CSIRO 2007), level of feeding or rumen outflow rate (AFRC 1993), and $\mathrm{pH}$, and digestion and passage rates from the rumen (NRC 2000). Although much information has been obtained for temperate pasture species and concentrate diets, there is a lack of knowledge concerning the variation in EMPS across tropical grass and legume species and the effects of seasonal conditions on this.
Low values for EMPS, <130 g MCP/kg DOMI, have been recorded for cattle consuming tropical forages (e.g. Kennedy 1982; Poppi et al. 1997; Panjaitan et al. 2010, 2015; Tuyen et al. 2015). However, the majority of these studies have been conducted in metabolism crates or pens and often with cattle consuming chaffed, mature hays and it is difficult to relate these conditions to those encountered by cattle grazing tropical pastures, which are characteristically heterogeneous in terms of both species composition and plant morphology (Stobbs 1975).

Measurement of MCP production in grazing ruminants has been hampered by the lack of a simple and accurate method of determination. Traditional methods required the use of postruminally cannulated animals, the employment of prolonged, steady, intraruminal infusion of markers and procedures for measuring digesta flow and for separation of microbes from digesta (Beever et al. 1986; Cruickshank et al. 1992). Bowen et al. (2009) proposed a new method of estimating MCP 
production in grazing cattle. It involved continuous intravenous jugular infusion of chromium (Cr)-EDTA and measurement of both $\mathrm{Cr}$ and purine derivative (PD) concentrations in spot urine samples to estimate urine output and, thereby, total PD excretion. Furthermore, Bowen et al. (2006) proposed adjustments to the equation Chen and Gomes (1995) used to estimate MCP production in the form of a lower estimate of endogenous PD excretion for Bos indicus compared with B. taurus cattle. Combined, these advances make it more feasible to make estimates of MCP production in B. indicus cattle grazing tropical pastures, that are typical of the beef cattle industry in northern Australia.

The objectives of the present study were, first, to estimate MCP production and EMPS in cattle grazing a range of tropical pasture types over varying seasonal conditions and, second, to study the relationships between various dietary and animal parameters, and EMPS. The tropical pasture types studied were representative of those grazed by cattle in northern Australia. Some aspects of the research have appeared elsewhere (Bowen et al. 2001, 2003, 2008a, 2008b, 2009, 2010a, 2010b).

\section{Materials and methods}

All procedures were approved by the Queensland Department of Primary Industries' Animal Ethics Committee.

\section{Site, pastures and animals}

Seven grazing experiments were conducted at Brian Pastures Research Station, $18 \mathrm{~km}$ east-south-east of Gayndah, in northern Australia $\left(25^{\circ} 39^{\prime} \mathrm{S}, 151^{\circ} 44^{\prime} \mathrm{E}\right.$, elevation $\left.131 \mathrm{~m}\right)$. The research station is located within the subhumid, subtropical region of Queensland, with an average annual rainfall of $708 \mathrm{~mm}$ characterised by high annual variability and a strong summer incidence (70\% occurs between October and March). Seven pasture types were studied sequentially over the 13-month period, January 2000 to January 2001, the order being determined by seasonal pasture availability and rainfall. The pasture types were native tropical grass $\left(C_{4}\right)$ pasture, typical of the southern speargrass region of Queensland (major species black speargrass (Heteropogon contortus) and forest bluegrass (Bothriochloa bladhii)) grazed in the (i) early wet season (NPEW), (ii) wet-dry transitional period (NPT) and (iii) dry season (NPD); introduced tropical grass $\left(\mathrm{C}_{4}\right)$ pasture of creeping bluegrass (Bothriochloa insculpta cv. Bisset; $\mathrm{BB}$ ), grazed in the mid-wet season; introduced tropical legumes $\left(\mathrm{C}_{3}\right)$ of Dolichos lablab (Lablab purpureus cv. Highworth; LL) and butterfly pea (Clitoria ternatea $\mathrm{cv}$. Milgarra; $\mathrm{BP}$ ); and the temperate grass $\left(\mathrm{C}_{3}\right)$ pasture of annual ryegrass (Lolium multiflorum cv. Tetila; RG) which was included as a positive, temperate control. All pastures, except for LL and RG, were dryland (non-irrigated) and all except for RG were continuously grazed during the experimental period. Grazing of RG was conducted according to a four-paddock rotational system with an average of 5 days of grazing followed by 15 days of rest. The speed of the rotation was varied according to the pasture growth rate so that the pasture was grazed from $\sim 20 \mathrm{~cm}$ to no lower than $5 \mathrm{~cm}$ (minimum of $2.5 \mathrm{~cm}$ remaining leaf). If the pasture growth rate was excessive, additional cattle were brought on to the paddocks being vacated, to graze the pasture down to the 5-cm level. On the day the cattle vacated each RG paddock, fertiliser was applied (76 kg urea/ha) and irrigation was undertaken (12 or $25 \mathrm{~mm}$ ).

Six to eight animals from a group of eight rumen-fistulated (RF) Brahman $(>75 \%$ B. indicus $)$ steers were used in each of the grazing experiments. At the commencement of experimentation, the steers were $\sim 15$ months of age, with an average liveweight of $329 \pm 10.8 \mathrm{~kg}$ and, by the final pasture experiment, were $\sim 27$ months of age and $471 \pm 10.6 \mathrm{~kg}$. Two to four animals from a group of four oesophageal-fistulated (OF) Brahman ( $>75 \%$ $B$. indicus) steers also grazed each pasture type concurrently with the RF steers and were $\sim 5$ years of age and $599 \pm 27.3 \mathrm{~kg}$ in liveweight at the commencement of experimentation.

\section{Marker dosing and sampling of RF steers}

Each experimental period for the RF steers consisted of at least 2 weeks of preliminary grazing, during which markers were introduced, followed by 1 week of marker sampling (RF sampling period). CrEDTA (278-1086 mg Cr/L, depending on the experiment) was infused intravenously via a jugular catheter at a rate of $16.5-20.5 \mathrm{~mL} / \mathrm{h}$. The CrEDTA solution was delivered continuously for 6 days, commencing 1 day before the start of the sampling period, via a battery-operated, peristaltic infusion pump carried in a back-pack worn by each steer. Twenty grams of ytterbium (Yb)-marked hay (oven-dried, 3-mm ground Rhodes grass (Chloris gayana)) was dosed directly into the rumen twice daily at 0730 hours and 1630 hours, for the 5 days preceding the start of the sampling period and for the first 5 days of sampling. $\mathrm{The} \mathrm{Yb}$ concentration was varied for each experiment so that the dose rate would approximate $55 \mathrm{mg} \mathrm{Yb/kg}$ estimated dry matter intake of the RF steers. One controlled release device designed for 300-650-kg cattle, containing $8 \mathrm{~g}$ n-dotriacontane $\left(\mathrm{C}_{32}\right)$ plus $8 \mathrm{~g}$ n-hexatriacontane $\left(\mathrm{C}_{36}\right)$, (Alkane $\mathrm{CRC}^{\circledR}$, Captec, Auckland, New Zealand), was inserted into the rumen of each RF steer 7 days before the commencement of each sampling period. The capsule was removed 5 days after sampling commenced. The linear delivery rate of each controlled release device was measured daily during the sampling period, by withdrawing the device through the rumen cannula and measuring the core displacement at four points of the circumference with Vernier callipers.

Urine, faecal and rumen-fluid samples were collected from RF steers over the first 5 days of each RF sampling period. Ten sampling times were randomly allocated to the 5 days, with two sampling times per day, each separated by at least 9 h. Faecal samples were freeze-dried before analysis for organic matter $(\mathrm{OM})$ and $\mathrm{Yb}$ concentration. Subsamples of urine were taken on each occasion for $\mathrm{Cr}$ and $\mathrm{PD}$ analysis. Urine subsamples for PD analysis were immediately diluted 1 in 10 with $0.1 \mathrm{M}$ ammonium phosphate $\left(\mathrm{NH}_{4} \mathrm{H}_{2} \mathrm{PO}_{4}\right)$ buffer. The buffered subsamples were frozen before analysis for PD concentration. Urine subsamples for $\mathrm{Cr}$ analysis were frozen, undiluted, until analysis. Rumen fluid was collected from at least three different sites in the rumen of each steer, and $\mathrm{pH}$ was determined immediately after sample collection with a portable $\mathrm{pH}$ meter. Subsamples of rumen fluid kept for volatile fatty acid (VFA) analysis were frozen and later bulked over the 10 sampling times for each steer. Additionally, subsamples were kept for ammonia-nitrogen $(\mathrm{N})$ analysis for six of the 10 sampling times. These were acidified to $\mathrm{pH} \leq 3$ by adding concentrated 
sulfuric acid. Two rumen-fluid samples per steer, taken before and after the main daily grazing periods (i.e. 0600 hours and 2030 hours), were kept for protozoa enumeration from all treatments except NPT. To preserve these samples, $4 \mathrm{~mL}$ of strained, stirred rumen fluid was added to a $16 \mathrm{~mL}$ of formal saline solution $(0.9 \% \mathrm{NaCl}$ and $4 \%$ formaldehyde $(\mathrm{w} / \mathrm{w})$ in water). The enumeration procedure involved counting protozoa in a known volume of rumen fluid under a light microscope using $\times 100$ magnification and a counting chamber (Hawksley, Lancing, Sussex, England) of 0.2-mm depth and divided into $0.2-\mathrm{mm}^{2}$ grids. Identification of protozoa species was performed with reference to Dehority (1993).

On Day 6 of the RF sampling period, a single dose of concentrated CrEDTA (12 mg Cr/mL) solution, together with the final $\mathrm{Yb}$ dose, was delivered into the rumen of each $\mathrm{RF}$ steer at 0900 hours, following the morning grazing period. The concentrated CrEDTA solution was injected into at least four different sites in the rumen and washed in with water. The volume of CrEDTA solution injected was varied for each experiment so that the dose rate would approximate $0.67 \mathrm{~g} \mathrm{Cr} /$ $100 \mathrm{~kg}$ average liveweight of the RF steers. Rumen-fluid samples were collected from at least three different sites in the rumen of each steer and bulked for $\mathrm{Cr}$ analysis at times 4, 8, 12, 21, 25, 29, 33, 36 and $48 \mathrm{~h}$ after dosing. Rumen-digesta samples were collected from three different sites within the rumen of each steer and bulked for $\mathrm{Yb}$ analysis at times 4, 8, 12, 25, 36 and $48 \mathrm{~h}$ after final $\mathrm{Yb}$-marker dosing.

\section{Extrusa sampling of OF steers}

After a minimum of 6 days preliminary grazing on the treatment paddock, extrusa samples were collected from OF steers at least twice, often on consecutive days, during the RF sampling period. OF steers were held in yards off pasture overnight before sampling at 0800 hours the following morning. Extrusa samples were mixed thoroughly, then placed directly onto dry ice and later frozen. Subsamples were freeze-dried before analyses and incubation in nylon bags.

\section{Pasture sampling}

Pasture measurements in the trial paddocks were made just before the commencement of the RF sampling period. The BOTANAL procedure described by Tothill et al. (1992) was used to assess pasture mass and species composition for the NPEW, NPT and NPD pastures. On BB, LL, BP and RG pastures, mass was estimated from the average of cut quadrats. Pasture height was measured with a ruler in each individual quadrat. Additional random quadrats or plants were cut in each pasture and bulked, mixed and progressively halved until a manageable portion remained for sorting into green leaf, green stem and dead components. In addition, on one occasion during the RF sampling period for each pasture type, representative samples of pasture leaf were plucked by hand from the test pasture between 1000 hours and 1100 hours, and placed directly onto dry ice before freeze-drying and analysis for total non-structural carbohydrate concentration and for determination of nitrate concentration ( $R G$ pasture only).

\section{Nylon-bag incubation of extrusa}

At the completion of the grazing studies, a representative bulk extrusa sample (3-mm ground) from each of the seven pasture types was incubated in nylon bags (monofilament polyester, $24 \times$ $10 \mathrm{~cm}$ outer dimension, pore size $45 \mu \mathrm{m}$; Allied Filter Fabrics), in RF steers consuming a standard diet, for determination of extrusa rumen-degradable protein (RDP) concentration. The effective protein degradability was determined by measuring the rate of disappearance of neutral detergent insoluble $\mathrm{N}$ less acid detergent insoluble $\mathrm{N}$ in the incubated extrusa. The methods and results of this work are reported in Bowen et al. (2008b).

\section{Analytical procedures}

Dry matter (DM) content of pasture samples and nylon-bag residue was determined by drying to a constant weight in a forced-draught oven at $60-70^{\circ} \mathrm{C}$. The samples were milled to $<1 \mathrm{~mm}$ before chemical analysis. The ash content of faeces, extrusa and nylon-bag residue was determined by heating dry samples in an electric muffle furnace (thermogravimetric analyser TGA-601, LECO Corporationa; St Joseph, MI, USA) at $610^{\circ} \mathrm{C}$ to a constant weight under an atmosphere of oxygen. Extrusa samples were analysed for total $\mathrm{N}$ concentration by a combustion method (Sweeney 1989), using an Elementar RapidN analyser (Elementar Analysensysteme GmbH, Hanau, Germany). Neutral detergent insoluble $\mathrm{N}$ and acid detergent insoluble $\mathrm{N}$ concentrations were determined on the residue of rumen-incubated extrusa samples by analysis for fibre and then N. Ash-free neutral detergent fibre (NDF) and ash-free acid detergent fibre (ADF) were determined using the Fibretec 2021 Fibrecap system developed by Foss Tecator (Foss Tecator 2002a, 2002b). Nitrate concentration was determined colourimetrically on leaf samples from the RG pasture by Merckoquant nitrate-test strips (MERK, Darmstadt, Germany). Standard nitrate solutions were used to improve precision and reproducibility, and the test strips were validated against a nitrate electrode. Total non-structural carbohydrate concentration was determined on leaf samples using a variation of the method of Weier et al. (1977), involving an enzyme digestion and extraction procedure followed by ferricyanide colourimetric analysis. Alkane profiles were determined on plant, extrusa and faecal samples by direct saponification, with minor variations to the procedure described by Dove (1992). Samples were extracted with n-hexane in place of n-heptane. Quantification of the n-alkanes $\left(\mathrm{C}_{29}-\mathrm{C}_{36}\right)$ was performed using a gas chromatograph (Shimadzu GC-17A) fitted with a capillary column (Alltech EC-1). Standards were mixed $\left(\mathrm{C}_{29}-\mathrm{C}_{36}\right)$ commercial n-alkanes and covered a range of concentrations.

In vitro organic matter digestibility (IVOMD) was determined on the extrusa samples using a two-stage technique (Tilley and Terry 1963), as modified by Minson and McLeod (1972). Rumen fluid was collected from a rumen-fistulated steer grazing tropical grass pasture (non-standard diet). The IVOMD of RG extrusa was determined using pepsin-cellulase technique, based on methods of McLeod and Minson (1978, 1980). For both methods, the IVOMD values were corrected by including standard pasture samples of known in vivo digestibility in the assays. 
The concentrations of VFA present in rumen-fluid samples were determined by gas chromatography, using a polar capillary column (DB-FFAP), after initial protein precipitation with metaphosphoric acid. Prior to determination of rumen ammonia-N concentration, rumen fluid was shaken and then centrifuged (2600 g for $12 \mathrm{~min}$ ) to obtain a clear supernatant. After a reaction, which converts ammonia to form an indophenol dye (Bolleter et al. 1961), spectrophotometric determination was conducted on an Olympus AU400 clinical analyser.

Acidified and buffered urine samples were thawed, filtered with $0.2-\mu \mathrm{m}$ Alltech cellulose nitrate or acetate membrane filter, followed by a C18, 300-mg filter, and analysed for PD concentration using a high-performance liquid chromatograph (Waters Model 600 E, USA) according to the method outlined by Balcells et al. (1992). Urine samples were analysed for $\mathrm{Cr}$ concentration using a Finnegan inductively coupled plasma mass spectrometer. Samples were first deproteinised by diluting $1 \mathrm{~mL}$ of sample with $4 \mathrm{~mL}$ of $6 \%$ trichloracetic acid. Rumen-fluid samples were centrifuged $(2600 \mathrm{~g}$ for $10 \mathrm{~min}$ ) before analysis for Cr using a Varian 220FS atomic absorption spectrometer with an air acetylene flame. Faecal and digesta samples were analysed for $\mathrm{Yb}$ by using the same spectrometer but with a nitrous oxide-acetylene flame and emission detection. The faecal and digesta samples were prepared for $\mathrm{Yb}$ analysis by ashing $\left(500^{\circ} \mathrm{C}\right.$ for $\left.8 \mathrm{~h}\right)$ in a muffle furnace, followed by an acid digest using nitric and hydrochloric acids and potassium chloride as in de Vega and Poppi (1997).

\section{Calculations}

Rumen-degradable protein (RDP) concentration as a proportion of total extrusa crude protein (CP) was determined following estimation of undegradable dietary protein ( $\mathrm{g} / \mathrm{kg} \mathrm{DM})$, using the equation described by Broderick (1994) as detailed in Bowen et al. (2008b). The non-fibre carbohydrate concentration in extrusa was calculated by difference from measured components and assuming an ether extract (EE) value of $30 \mathrm{~g} / \mathrm{kg} \mathrm{DM}$ (NRC $2000)$, i.e. non-fibre carbohydrate $(\mathrm{g} / \mathrm{kg} \mathrm{DM})=\mathrm{OM}(\mathrm{g} / \mathrm{kg} \mathrm{DM})-$ $(\mathrm{NDF}+\mathrm{CP}+\mathrm{EE} ; \mathrm{g} / \mathrm{kg} \mathrm{DM})$. DOMI of RF steers grazing each of the pasture types were estimated using both $\mathrm{Yb}$ and n-alkane faecal-output markers. Faecal output for individual RF steers was estimated assuming a faecal recovery of 1 for the $\mathrm{Yb}$ marker (Siddons et al. 1985; Galyean et al. 1986) and 0.95 for the $\mathrm{C}_{36}$ n-alkane (Dove and Mayes 1991). OM intake and DOMI of individual RF steers were then estimated using faecal-output estimates in conjunction with the average IVOMD for each extrusa sample. In contrast to the negligible concentrations $(<5 \mathrm{mg} / \mathrm{kg} \mathrm{DM})$ of the dosed $\mathrm{C}_{36}$ n-alkane marker detected in cut pasture, OF extrusa, or faeces of undosed OF steers, significant levels of the dosed $\mathrm{C}_{32}$ n-alkane were detected in these components for all pasture types. Thus, calculations of faecal output and intake using the n-alkane marker technique were performed using the dosed $\mathrm{C}_{36}$ n-alkane only. Total PD excretion (sum of allantoin, uric acid, hypoxanthine and xanthine) in urine was calculated from PD concentrations in spot urine samples using the measured $\mathrm{Cr}$ infusion rates for each animal on each day and adjusting for 0.90 urinary recovery, as determined by Bowen et al. (2009). The flow of MCP to the intestines of steers was calculated using the equations proposed by Chen and Gomes (1995). These calculations were performed using the value for endogenous PD excretion determined for high-content $(>75 \%) \mathrm{B}$. indicus cattle by Bowen et al. (2006), i.e. $190 \mu \mathrm{mol} / \mathrm{kg} \mathrm{W}^{0.75}$.day. EMPS was expressed as g MCP/kg DOMI, where DOMI was estimated using the $\mathrm{Yb}$ faecal-output marker only, due to the greater number of experiments reporting the recovery in the faeces of $\mathrm{Yb}$ than of $\mathrm{C}_{36} \mathrm{n}$-alkane (Galyean et al. 1986; Dove and Mayes 1991). The fractional outflow rate (FOR) of $\mathrm{Cr}$ and $\mathrm{Yb}$ in rumen fluid and digesta, respectively, was determined by regressing the natural $\log (\ln )$ of $\mathrm{Cr}$ and $\mathrm{Yb}$ concentration against time, with the rate constant, $\mathrm{k}$, determined as the slope of the regression so that FOR $(\% / \mathrm{h})=-\mathrm{k} \times 100$.

\section{Statistical analyses}

So as to study a range of pasture types and conditions, it was necessary to conduct separate grazing experiments, sequentially, according to pasture availability and seasonal conditions. Thus, it was not valid to conduct statistical comparisons across pasture types due to the possible period effects. Within pasture type, variation, expressed as means and standard errors, allows comparative comments, but inference is necessarily limited.

\section{Results}

The quantitative values for each pasture species are of primary interest, but overall relationships between diet characteristics and EMPS are discussed. General conclusions have been drawn where appropriate.

\section{Pasture characteristics and chemical composition of extrusa}

Rainfall at Brian Pastures Research Station for the 12-month period covering the majority of experimental work (January to December 2000) was $577 \mathrm{~mm}$ and was below the long-term annual average of $708 \mathrm{~mm}$. The average botanical composition $(\mathrm{g} / \mathrm{kg}$ total $\mathrm{DM})$ of the native tropical grass pasture studied at three stages of the season (NPEW, NPT and NPD) was 483 black speargrass (Heteropogon contortus), 395 forest bluegrass (Bothriochloa bladhii) and 52 Queensland bluegrass (Dichanthium sericium), with the remainder consisting of other native and introduced grasses and legumes and broad-leaved weeds. Pasture mass, height and the quantity of green leaf material in the pasture varied widely across the seven pasture types studied (Table 1). The greatest pasture mass and height were measured for LL, while RG pasture had the greatest proportion of green leaf in total DM. Native tropical grass pasture displayed a trend of increasing pasture mass and height, and decreasing green leaf mass, from the early wet season (NPEW), to the wet-dry transitional period (NPT), to the dry season (NPD). There was a large range in chemical composition of the extrusa collected from OF steers grazing the seven pasture types (Table 2). In particular, tropical grass pastures (NPEW, NPT, NPD and BB) had much lower CP concentration and higher NDF and ADF concentrations than did tropical legumes (LL and BP) and RG. The very high CP concentration of the RG pasture was also associated with a high nitrate concentration in plucked leaf samples (62 $\mathrm{g}$ $\left.\mathrm{KNO}_{3} / \mathrm{kg} \mathrm{DM}\right)$. 
Table 1. Characteristics of pastures grazed by steers Treatment descriptions are given in the text

\begin{tabular}{llcccccc}
\hline Characteristic & \multicolumn{4}{c}{ Tropical grass } & \multicolumn{2}{c}{ Tropical legume } & \multicolumn{2}{c}{ Temperate grass } \\
& NPEW & NPT & NPD & BB & LL & BP $^{\mathrm{A}}$ & \multicolumn{2}{c}{ RG } \\
\hline Pasture mass (kg DM/ha) & 675 & 2711 & 2803 & 3043 & 6349 & 1277 & 1588 \\
Height (cm) & 12.2 & 18.8 & 25.5 & 11.8 & 90.5 & 38.3 & 26.6 \\
& & & \multicolumn{2}{c}{ Plant components $(\mathrm{g} / \mathrm{kg}$ total DM $)$} & & & \\
Green leaf & 574 & 295 & 29 & 218 & 381 & 253 & 800 \\
Green stem & 268 & 352 & 86 & 242 & 610 & 515 & 92 \\
Dead material & 159 & 352 & 885 & $540^{\mathrm{B}}$ & 9 & 0 & 108 \\
Pods & - & - & - & - & - & 232 & - \\
\hline
\end{tabular}

${ }^{\mathrm{A}}$ Figures given for butterfly pea species only, which comprised $\sim 700 \mathrm{~g} / \mathrm{kg}$ of total pasture DM on offer. Other species present in the trial paddock included various dry grass species, dry sorghum (Sorghum bicolour) stalks and weeds.

${ }^{B}$ Dead material included previous season's growth that was still connected to the base of the plant.

Table 2. Composition of extrusa and plucked leaf for steers grazing six tropical pastures and ryegrass

Treatment descriptions are given in the text; results are presented as mean \pm s.e. ADF, acid detergent fibre; CP, crude protein; DM, dry matter; NDF, neutral detergent fibre; $\mathrm{NFC}^{\mathrm{A}}$, non-fibre carbohydrate; $\mathrm{OM}$, organic matter, $\mathrm{OF}$, oesophageal fistulated; RDP, rumen-degradable protein; TNSC, total non-structural carbohydrates

\begin{tabular}{|c|c|c|c|c|c|c|c|}
\hline \multirow[t]{2}{*}{ Parameter } & \multicolumn{4}{|c|}{ Tropical grass } & \multicolumn{2}{|c|}{ Tropical legume } & \multirow{2}{*}{$\begin{array}{c}\text { Temperate grass } \\
\text { RG }\end{array}$} \\
\hline & NPEW & NPT & NPD & $\mathrm{BB}$ & LL & BP & \\
\hline Number of OF steers & 2 & 4 & 4 & 2 & 4 & 3 & 2 \\
\hline \multicolumn{8}{|c|}{ Extrusa } \\
\hline $\mathrm{OM}$ (g/kg DM) & $859 \pm 3.0$ & $859 \pm 17.4$ & $865 \pm 3.8$ & $864 \pm 1.5$ & $872 \pm 3.3$ & $876 \pm 3.2$ & $802 \pm 13.0$ \\
\hline $\mathrm{CP}(\mathrm{g} / \mathrm{kg} \mathrm{DM})$ & $79 \pm 3.4$ & $42 \pm 1.3$ & $27 \pm 0.8$ & $59 \pm 0.0$ & $253 \pm 7.8$ & $142 \pm 11.5$ & $354 \pm 6.3$ \\
\hline RDP (g/g CP) & 0.86 & 0.83 & 0.82 & 0.91 & 0.97 & 0.95 & 0.98 \\
\hline NDF (g/kg DM) & $643 \pm 15.0$ & $615 \pm 11.3$ & $657 \pm 3.8$ & $570 \pm 1.5$ & $245 \pm 11.0$ & $393 \pm 18.7$ & $294 \pm 6.3$ \\
\hline $\mathrm{ADF}(\mathrm{g} / \mathrm{kg} \mathrm{DM})$ & $333 \pm 7.0$ & $313 \pm 9.7$ & $378 \pm 1.9$ & $317 \pm 5.5$ & $179 \pm 3.8$ & $271 \pm 9.1$ & $154 \pm 3.0$ \\
\hline $\mathrm{NFC}^{\mathrm{A}}(\mathrm{g} / \mathrm{kg} \mathrm{DM})$ & 107 & 172 & 151 & 205 & 344 & 311 & 124 \\
\hline \multicolumn{8}{|c|}{ Plucked leaf } \\
\hline $\operatorname{TNSC}^{\mathrm{B}}(\mathrm{g} / \mathrm{kg} \mathrm{DM})$ & 99 & 106 & 42 & 108 & 129 & 157 & 115 \\
\hline
\end{tabular}

${ }^{\mathrm{A}}$ Determined by calculation, from chemical composition of extrusa.

${ }^{\mathrm{B}}$ Determined from leaf plucked from each pasture type; expressed as glucose equivalents, i.e. g glucose $/ \mathrm{kg} \mathrm{DM}$.

Pasture digestibility and estimated intake by steers

The IVOMD values determined on OF extrusa, and corrected using in vivo standards, also showed a large range across pasture types (Table 3), with RG having the highest value and BP the lowest. Variability in IVOMD among steers was greatest when grazing the tropical-legume pastures (LL and $\mathrm{BP}$ ) and the native pasture in the wet-dry and dry seasons (NPT and NPD). There was a similarly wide range across the seven pastures in the DOMI of grazing RF steers, estimated using IVOMD in conjunction with either dosed $\mathrm{Yb}$ or dosed $\mathrm{C}_{36} \mathrm{n}$-alkane as a faecal-output marker (Table 3). The lowest intakes (as a proportion of liveweight) were recorded on NPD and BP pastures. As expected, IVOMD and DOMI declined for steers grazing native tropical grass pasture as the season progressed from the early wet to the dry season. The difference in estimated DOMI determined using the $\mathrm{Yb}$ or $\mathrm{C}_{36}$ n-alkane markers varied with pasture type. When DOMI was expressed as kilograms per day, the alkane estimate differed from the $\mathrm{Yb}$ estimate by less than $\%$ for NPT, BB, LL and BP, and less than $15 \%$ for NPEW and RG. The largest discrepancy between the two methods was recorded for NPD, for which the alkane estimation was $24 \%$ lower than that using the $\mathrm{Yb}$ marker. There was a linear relationship between the two methods, as follows: alkane-estimated DOMI $=0.945 \times$ Yb-estimated DOMI $+0.627, r^{2}=0.91, P<0.01$, where DOMI was expressed as $\mathrm{kg} / \mathrm{day}$.

\section{MCP synthesis and EMPS}

While there was some variation in MCP flow among animals on a pasture type, as indicated by the standard error, this was small relative to the variation among pasture types, with the exception of steers grazing RG (Table 4). Similarly, there was a large range in EMPS across pasture types. Mature tropicalgrass pastures (NPT and NPD) were associated with very low EMPS, while values of EMPS for early to mid-season tropical grasses (NPEW and BB) were almost three-fold higher, but still less than for tropical legumes (LL and BP). The temperate-pasture RG was associated with EMPS values $\sim 1.5$ times higher than that for the tropical legumes. The trend for EMPS followed the same trend as the estimated 
concentration of RDP per kilogram of DOMI for the RF steers (Table 4).

\section{Rumen parameters}

Steers grazing the two tropical legumes (LL and BP) and RG had high rumen ammonia-N concentrations compared with those grazing the tropical grass pastures (Table 5). Steers grazing early to mid-wet season tropical grass $\left(\mathrm{C}_{4}\right)$ pastures $(\mathrm{NPEW}$ and $\mathrm{BB}$ ) had high rumen fluid and particle FOR, which were in a range similar to those grazing the $\mathrm{C}_{3}$ species (tropical legumes and $\mathrm{RG}$ ), while steers grazing mature native $\mathrm{C}_{4}$ grass pasture (NPD) had a very low FOR (Table 5). Despite the determination of FOR for both $\mathrm{Cr}$ and $\mathrm{Yb}$ markers being undertaken under non-steady-state conditions, the correlation coefficients for the regressions of $\ln (\mathrm{Cr}$ concentration $)$ and $\ln (\mathrm{Yb}$ concentration $)$ against time were extremely high on all pasture types, with usually $r=0.99$. A linear relationship between particle FOR and fluid FOR was observed $\left(r^{2}=0.77, P=0.01\right)$; however, the very low fluid FOR value for NPD had a large influence on the regression. The lowest average rumen-fluid $\mathrm{pH}$ was measured on LL pasture and the highest on RG pasture (Table 5). Except for steers grazing the LL and BP pastures, rumen-fluid $\mathrm{pH}$ was generally maintained above 6.0 during the diurnal cycle. On LL pasture, $\mathrm{pH}$ fell below 6.0 in five of six RF steers on at least 1 , and up to 7 of the 10 sampling occasions. On BP pasture, rumenfluid $\mathrm{pH}$ fell below 6.0 in seven of eight steers on at least 1 , and up to 5 , of the 10 sampling occasions. Total VFA concentration

Table 3. In vitro organic-matter digestibility (IVOMD) of extrusa collected from oesophageal-fistulated steers grazing six tropical pastures and ryegrass and digestible organic-matter intake (DOMI) predicted using IVOMD in conjunction with either ytterbium (Yb) or $\mathrm{C}_{36} \mathrm{n}$-alkane faecal-output markers in rumen-fistulated steers grazing the same pasture types

Treatment descriptions are given in the text; results are presented as mean \pm s.e. LW, liveweight

\begin{tabular}{|c|c|c|c|c|c|c|c|}
\hline \multirow[t]{2}{*}{ Parameter } & \multicolumn{4}{|c|}{ Tropical grass } & \multicolumn{2}{|c|}{ Tropical legume } & \multirow{2}{*}{$\begin{array}{c}\text { Temperate grass } \\
\text { RG }\end{array}$} \\
\hline & NPEW & NPT & NPD & BB & LL & BP & \\
\hline IVOMD (g/kg) & $681 \pm 1.4$ & $656 \pm 10.5$ & $608 \pm 4.4$ & $724 \pm 1.0$ & $777 \pm 7.1$ & $585 \pm 8.8$ & $827 \pm 0.5$ \\
\hline DOMI using $\mathrm{Yb}(\mathrm{kg} / 100 \mathrm{~kg} \mathrm{LW})$ & $1.75 \pm 0.048$ & $1.41 \pm 0.021$ & $1.08 \pm 0.049$ & $1.46 \pm 0.065$ & $1.93 \pm 0.216$ & $0.82 \pm 0.029$ & $1.35 \pm 0.105$ \\
\hline $\begin{array}{l}\text { DOMI using } \mathrm{C}_{36} \mathrm{n} \text {-alkane } \\
(\mathrm{kg} / 100 \mathrm{~kg} \mathrm{LW})\end{array}$ & $1.51 \pm 0.057$ & $1.39 \pm 0.045$ & $0.82 \pm 0.019$ & $1.48 \pm 0.048$ & $2.00 \pm 0.117$ & $0.85 \pm 0.046$ & $1.18 \pm 0.087$ \\
\hline
\end{tabular}

Table 4. Microbial protein (MCP) synthesis, efficiency of microbial protein synthesis (EMPS) and concentration of rumen-degradable protein (RDP) per kilogram digestible organic matter intake (DOMI) for rumen-fistulated (RF) steers grazing six tropical pastures and ryegrass Treatment descriptions are given in the text; results are presented as mean \pm s.e. LW, liveweight

\begin{tabular}{|c|c|c|c|c|c|c|c|}
\hline \multirow[t]{2}{*}{ Parameter } & \multicolumn{4}{|c|}{ Tropical grass } & \multicolumn{2}{|c|}{ Tropical legume } & \multirow{2}{*}{$\begin{array}{c}\text { Temperate grass } \\
\text { RG }\end{array}$} \\
\hline & NPEW & NPT & NPD & BB & LL & $\mathrm{BP}$ & \\
\hline RDP supply (g/kg DOMI) & 117 & 61 & 42 & 86 & 363 & 262 & 525 \\
\hline Number of RF steers & 8 & 6 & 8 & 8 & 6 & 8 & 6 \\
\hline MCP synthesis (g/100 kg LW) & $148 \pm 7.0$ & $36 \pm 3.1$ & $38 \pm 2.8$ & $131 \pm 4.6$ & $247 \pm 10.4$ & $117 \pm 7.8$ & $289 \pm 58.4$ \\
\hline EMPS (g MCP/kg DOMI) & $85 \pm 4.1$ & $26 \pm 2.2$ & $35 \pm 3.3$ & $90 \pm 3.3$ & $135 \pm 14.9$ & $144 \pm 11.6$ & $209 \pm 33.3$ \\
\hline
\end{tabular}

Table 5. Fractional outflow rates (FOR) for fluid and particles from the rumen, and pH and concentrations of ammonia-N and volatile fatty acids (VFA) and molar proportion of VFA in the rumen fluid of rumen-fistulated steers grazing six tropical pastures and ryegrass Treatment descriptions are given in the text; results are presented as mean \pm s.e. BCFA, branched-chain fatty acids

\begin{tabular}{|c|c|c|c|c|c|c|c|}
\hline \multirow[t]{2}{*}{ Parameter } & \multicolumn{4}{|c|}{ Tropical grass } & \multicolumn{2}{|c|}{ Tropical legume } & \multirow{2}{*}{$\begin{array}{c}\text { Temperate grass } \\
\text { RG }\end{array}$} \\
\hline & NPEW & NPT & NPD & $\mathrm{BB}$ & $\mathrm{LL}$ & $\mathrm{BP}$ & \\
\hline Ammonia-N (mg/L) & $17.0 \pm 1.37$ & $8.0 \pm 0.59$ & $22.5 \pm 3.74$ & $16.7 \pm 1.64$ & $378.0 \pm 10.20$ & $182.4 \pm 6.52$ & $382.3 \pm 7.56$ \\
\hline Fluid FOR $(\% / \mathrm{h})$ & $10.8 \pm 0.48$ & $7.6 \pm 0.36$ & $4.5 \pm 0.33$ & $9.5 \pm 0.37$ & $11.7 \pm 0.44$ & $8.4 \pm 0.70$ & $9.3 \pm 0.98$ \\
\hline Particle FOR $(\% / h)$ & $4.3 \pm 0.28$ & $3.0 \pm 0.14$ & $2.0 \pm 0.15$ & $4.4 \pm 0.24$ & $4.4 \pm 0.52$ & $2.8 \pm 0.25$ & $2.9 \pm 0.27$ \\
\hline Rumen fluid $\mathrm{pH}$ & $6.4 \pm 0.03$ & $6.6 \pm 0.04$ & $6.5 \pm 0.02$ & $6.3 \pm 0.05$ & $6.1 \pm 0.06$ & $6.3 \pm 0.05$ & $6.8 \pm 0.04$ \\
\hline Total VFA concentration (mM) & $23.0 \pm 1.13$ & $80.8 \pm 4.54$ & $67.5 \pm 2.26$ & $30.5 \pm 1.91$ & $169.6 \pm 6.94$ & $129.2 \pm 4.09$ & $99.6 \pm 2.47$ \\
\hline \multicolumn{8}{|c|}{ Molar proportions of VFA (\% of total) } \\
\hline Acetate & 71.7 & 76.0 & 73.3 & 72.1 & 65.8 & 66.9 & 63.4 \\
\hline Propionate & 17.5 & 12.4 & 14.5 & 19.0 & 17.3 & 17.0 & 16.8 \\
\hline Butyrate & 9.0 & 10.4 & 7.4 & 7.3 & 11.2 & 9.9 & 11.0 \\
\hline Valerate & 0.5 & 0.3 & 3.5 & 0.5 & 1.6 & 2.5 & 1.7 \\
\hline $\mathrm{BCFA}^{\mathrm{A}}$ & 1.3 & 0.9 & 1.4 & 1.1 & 4.1 & 3.8 & 7.1 \\
\hline
\end{tabular}

${ }^{\mathrm{A}} \mathrm{Sum}$ of iso-butyrate and iso-valerate. 
in the rumen fluid was very low $(<50 \mathrm{mM})$ on NPEW and BB pastures, and was lower than concentrations measured on mature tropical grass pasture (NPT and NPD; Table 5). Branched-chain fatty acid (BCFA) concentrations and molar proportions in the rumen fluid were very low in steers grazing tropical grass pastures and much lower than values for steers grazing LL, BP and RG pastures.

Protozoal concentrations in rumen fluid varied widely across the pastures studied (Fig. 1), being greatest for steers grazing LL pasture and least for those grazing NPD. However, there was little difference in protozoal concentrations, or in the proportions of species, between sampling times occurring before and after the main grazing periods (0630 hours and 2030 hours respectively), although steers grazing LL pasture had slightly depressed protozoal concentrations after the main grazing period. Entodinium spp. were present in the greatest proportion on all pasture types, except for BB pasture sampled at 0630 hours. Compared with the tropical legumes (LL and BP) and RG, relatively large proportions of holotrichs (Isotricha and Dasytricha genera) were recorded in steers grazing the tropical grass pastures (NPEW, NPD and BB).

\section{Relationship between EMPS and pasture and animal factors}

As demonstrated in Fig. 2, EMPS for cattle grazing tropical grass pasture (NPEW, NPT, NPD and BB) increased linearly, close to the line of $1: 1$, as RDP/DOMI (g/kg) values (from Table 4) increased towards $130 \mathrm{~g} \mathrm{RDP} / \mathrm{kg}$ DOMI. EMPS values for cattle grazing tropical legumes LL and BP fell close to the line delineating the lower limit of $130 \mathrm{~g} \mathrm{MCP} / \mathrm{kg}$ DOMI suggested in the feeding standards. The EMPS for cattle grazing the temperate grass, $\mathrm{RG}$, fell well above the upper range of $170 \mathrm{~g}$ $\mathrm{MCP} / \mathrm{kg}$ DOMI suggested in the feedings standards.

Linear relationships between EMPS and both NDF and ADF concentrations in extrusa were evident. These relationships were as follows: $\mathrm{EMPS}=-3.17 \times \mathrm{NDF}$ concentration +258.1 , $r^{2}=0.72, P<0.05 ; \mathrm{EMPS}=-6.72 \times \mathrm{ADF}$ concentration +289.9, $r^{2}=0.74, P<0.05$; where EMPS was expressed as $\mathrm{g} \mathrm{MCP} / \mathrm{kg}$ DOMI and the concentrations of NDF and ADF were expressed as $\mathrm{g} / \mathrm{kg}$ DM. However, no obvious relationships were evident between EMPS and non-fibre carbohydrate in extrusa, total nonstructural carbohydrate in plucked pasture leaf, DOMI (expressed as a proportion of liveweight), rumen-particle and rumen-fluid FOR, protozoal concentrations in rumen fluid or rumen-fluid $\mathrm{pH}$.

\section{Discussion}

The work reported here represents the first known attempt to estimate EMPS in cattle grazing tropical pastures typical of those used in the northern Australian beef industry, and utilised novel methodology including intra-jugular infusion of CrEDTA in cattle to determine urine output. This method (Bowen et al. 2009) proved sufficiently robust to estimate MCP production under field conditions, when used in association with measurement of PD concentration in spot samples of the urine. These approaches avoid the errors associated with using creatinine as an internal marker, given the variability in its excretion among individuals and with diet type (Faichney et al. 1995), and do not require post-ruminal fistulation of the animal and associated complicated procedures for determining digesta flow and for separation of microbes.

The EMPS in cattle grazing all the tropical grass pastures were well below the range proposed in the feeding standards of 130-170 g MCP/kg DOMI when there is adequate RDP for the rumen microbes (AFRC 1993; CSIRO 2007), but appeared to be directly related to RDP supply, which was limiting for these diets (Fig. 2). Importantly, even cattle grazing tropical grass pastures during the period of highest pasture quality in the early and midwet seasons (NPEW and BB) had relatively low EMPS values of 85 and $90 \mathrm{~g} \mathrm{MCP} / \mathrm{kg}$ DOMI respectively. Cattle grazing native grass pasture in the early wet season (NPEW) had EMPS values similar to those of cattle grazing introduced tropical grass pasture (BB). The EMPS values for native pasture declined rapidly with

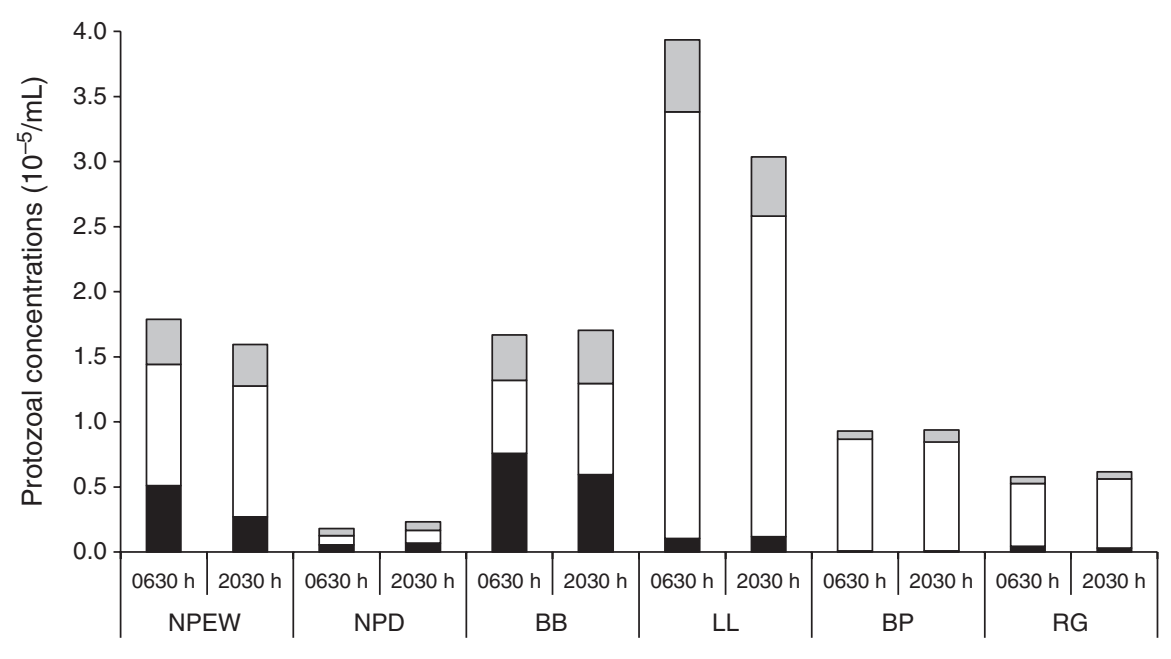

Pasture type and time of sampling

Fig. 1. Protozoal concentrations in the rumen fluid of steers grazing tropical pastures and ryegrass. Treatment descriptions are given in the text. Holotrichs (black bar), Entodinium spp. (white bar), other protozoal species from the Entodiniomorph group (excluding Entodinium spp) (grey bar). 


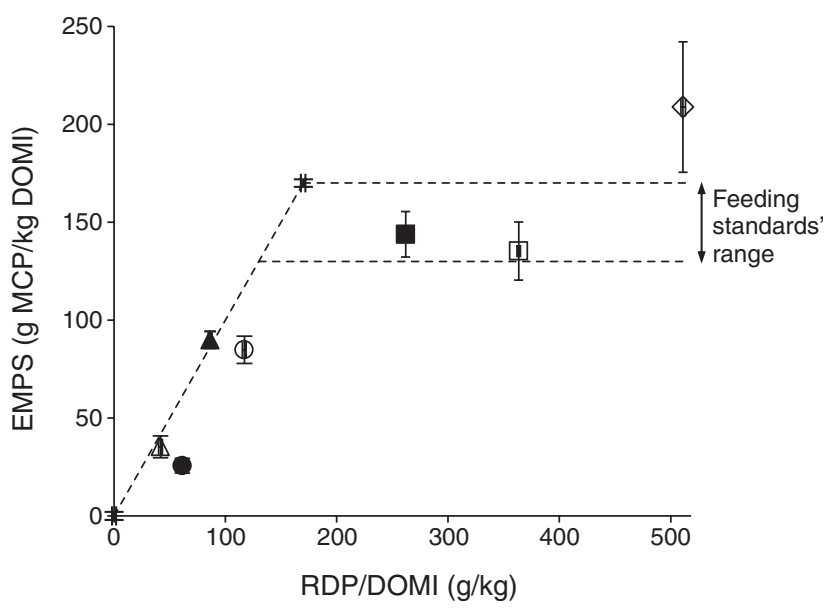

Fig. 2. Relationship between efficiency of microbial protein synthesis (EMPS) and the ratio of rumen degradable protein (RDP)/digestible organic matter intake (DOMI) in the diet of steers grazing six tropical pastures and ryegrass: NPEW $(\bigcirc)$, NPT $(\bullet)$, NPD $(\triangle), \mathrm{BB}(\boldsymbol{\Delta})$, LL $(\square)$, BP $(\square)$, RG $(\diamond)$. Treatment descriptions are given in the text. The dashed lines indicate the theoretical $y=x$ relationship and the range of EMPS given in the feeding standards.

increasing pasture maturity, reducing to $\sim 30 \mathrm{~g} \mathrm{MCP} / \mathrm{kg}$ DOMI during the wet-dry transitional period. Cattle grazing the tropical legumes, Dolichos lablab (LL) and butterfly pea (BP), had EMPS values that fell within the range of feeding-standards, while the corresponding value for annual ryegrass pasture $(R G)$ was much higher than that range, at $209 \mathrm{~g} \mathrm{MCP} / \mathrm{kg}$ DOMI.

As a general observation, values reported for EMPS in the literature in relation to temperate species of grass and legume eaten by both cattle and sheep fall either within or above the feeding-standards range (Hume and Purser 1974; Beever et al. 1978, 1986; Corbett and Pickering 1983; Cruickshank et al. 1992; Prior et al. 1998; Lee et al. 2002) and our recorded value for RG (209 g MCP/kg DOMI) was no exception. The contrasting low values for EMPS, $<130 \mathrm{~g} \mathrm{MCP} / \mathrm{kg}$ DOMI, recorded with cattle grazing tropical grass pastures in our study, are also consistent with those reported from feeding studies using tropical grasses either freshly harvested, or preserved as hays (Bolam 1998; Prior et al. 1998; Mullik 1999; Shem et al. 1999; Nsahlai et al. 2000; Panjaitan et al. 2010; Valaderes Filho et al. 2010) and are a consequence of low RDP/DOMI supply (Fig. 2). Two Brazilian collations of EMPS for tropical forages give a mean value of $120 \mathrm{~g} \mathrm{MCP} / \mathrm{kg}$ total digestible nutrients (Valaderes Filho et al. 2010) and $146 \mathrm{~g}$ MCP/kg DOMI (Detmann et al. 2014), with these values being in line with the Australian Feeding Standards (CSIRO 2007), given the variability in techniques used across various datasets. However, before the current experiments, no measurements of EMPS had been reported for cattle grazing high-quality tropical pastures in Australia. When ruminants graze pasture, diet selection invariably results in a higher $\mathrm{CP}$ concentration and digestibility in the diet than that on offer in the total pasture (Stobbs 1975; Corbett 1976). In addition, there are diurnal changes in the concentration of pasture non-structural carbohydrates (Fulkerson and Donaghy 2001), and diurnal patterns in grazing period and, hence, in rumen fill and digesta outflow rates from the rumen (Thomson et al. 1985). All of these factors can influence EMPS and it is for these reasons that researchers have previously attempted to verify data for animals offered temperate forages in pens by using animals grazing temperate pastures in the field (e.g. Corbett and Pickering 1983; Dove and Milne 1994). This was also the approach taken in the current experiments with tropical pastures. In the current experiments, EMPS in cattle grazing tropical grass pastures did not differ markedly from published values for tropical grass pastures when fed as cut forage or as hays. There are no reliable values in the literature for EMPS, measured for cattle consuming tropical legumes, with which to compare the values obtained in the current experiments. Kennedy (1982) measured a low EMPS (72 g MCP/kg DOMI) that was in the same range as the values obtained here for tropical grasses, in cattle consuming hay consisting of green panic and the tropical legume siratro (Macroptilium atropurpureum). However, the relative proportions of grass and legume in the hay were not given.

The wide range in EMPS values in grazing cattle in the present study reflected the similarly wide range in the dietary $\mathrm{CP}$ concentrations and, in turn, in RDP concentrations across the seven pasture types, although rumen-degradability of the protein was uniformly high across all pasture types, as reported in more detail in Bowen et al. (2008b). The dietary $\mathrm{CP}$ concentrations for cattle grazing the four tropical grass pastures, NPEW, NPT, NPD and BB, was low $(\leq 80 \mathrm{~g} / \mathrm{kg}$ $\mathrm{DM})$ and resulted in rumen ammonia concentrations that were below the accepted minimum rumen ammonia concentration of $50 \mathrm{mg}$ ammonia-N/L required for optimal MCP synthesis (Satter and Slyter 1974). It was evident that N supply was limiting EMPS in cattle grazing the four tropical grass pastures as EMPS increased linearly, very close to the line of $1: 1$, as the ratio of RDP/DOMI increased towards $130 \mathrm{~g} \mathrm{RDP} / \mathrm{kg}$ DOMI (Fig. 2), which is the lower limit of EMPS indicated in the feeding standards when RDP is adequate. Tropical legumes had RDP supply $>130 \mathrm{~g}$ RDP $/ \mathrm{kg}$ DOMI and resulted in EMPS in grazing steers within the feeding-standard range (130-170 g $\mathrm{MCP} / \mathrm{kg}$ DOMI). Temperate grass resulted in a very high EMPS of $>170 \mathrm{~g} \mathrm{MCP} / \mathrm{kg}$ DOMI, which was associated with a very high ratio of RDP/DOMI. The variation in EMPS observed here when RDP was presumably not limiting deserves further study, as this may indicate that other nutrients are limiting microbial protein production (e.g. non-structural carbohydrates, amino acids or BCFA) and could be targeted to increase EMPS. In this regard, the much higher BCFA concentrations associated with $R G$ than with other pasture types are of interest (RG > LL, BP > tropical grasses). The important role of BCFA in MCP production and EMPS was investigated by Hume (1970) and it may be speculated that adequate supply of these growth factors is needed if EMPS in cattle grazing tropical grasses is to achieve the high potential EMPS observed with temperate grasses.

No relationships were evident, across the seven grazing experiments reported here, between EMPS and non-fibre carbohydrate in extrusa or total non-structural carbohydrate concentration in pasture leaf. However, increasing fibre concentrations in the diets were associated with a linear decrease in EMPS. The concentrations of structural and non- 
structural carbohydrates in the diet are expected to influence EMPS through their effects on rates of fermentation, rates of passage and rumen $\mathrm{pH}$, all of which affect microbial maintenance requirements in the rumen (Dewhurst et al. 2000). Higher fibre concentration in pasture would be expected to lead to slower rates of passage and, thus, increased maintenance requirements for rumen microbes, which could explain the negative linear relationship between EMPS and fibre concentrations in the current experiments. However, there was no significant relationship between EMPS and either particle or fluid FOR across the range of pastures studied in the current experiments, despite the large range in FOR values across the seven pasture types $(4.5-11.7 \% / \mathrm{h}$ and $2.0-4.4 \% / \mathrm{h}$ for fluid and particle FOR respectively). This was unexpected as several in vitro and in vivo experiments have shown clear positive relationships between EMPS and particle and/or fluid FOR (e.g. Stouthamer and Bettenhaussen 1973; Djouvinov and Todorov 1994). Furthermore, most feeding standards recognise the importance of dilution rates on EMPS, with the AFRC (1993) in particular predicting EMPS with the use of an adjustment factor for rumen outflow rate. Two of the tropical grasses had low associated fluid FOR (NPD and NPT, $<8 \% / h$ ), but the other two (NPEW and BB) showed quite high values for fluid FOR of $>9 \% / \mathrm{h}$. It is probable that the limiting RDP supply for cattle grazing the tropical grass pastures was masking any effect of FOR. The relatively low particle and fluid FOR for the RG was surprising, given the high values obtained by others, e.g. $12-17 \% / h$ fluid FOR for cattle consuming freshly cut RG pasture (Beever et al. 1986) or grazing sheep (Cruickshank et al. 1992). The lower value in our experiment reflected the low DOMI $(\mathrm{kg} / 100 \mathrm{~kg} \mathrm{LW})$ of the cattle grazing RG, which is likely to be attributable to the unexpected high nitrate concentrations recorded in the leaves under the high-N fertilisation regime. The nitrate concentration of $62 \mathrm{~g} \mathrm{KNO}_{3} /$ $\mathrm{kg}$ DM measured in RG plucked leaf was over four times greater than the concentration of $15 \mathrm{~g} \mathrm{KNO}_{3} / \mathrm{kg} \mathrm{DM}$, which is commonly identified as being potentially hazardous to ruminant livestock (Dowling and McKenzie 1993). Additionally, the increased metabolic cost associated with detoxification of ammonia to urea in the liver and perhaps the high moisture concentration of the RG pasture $(886 \mathrm{~g} / \mathrm{kg})$ may have also had an effect on intake.

As discussed by Baker and Dijkstra (1999), protozoa can have a negative effect on EMPS by causing considerable intraruminal recycling of $\mathrm{N}$, as well as through competition with bacteria for substrates. There was no clear relationship between protozoal concentrations and EMPS across our experiments, e.g. steers grazing LL pasture had high protozoal concentrations in the rumen fluid, but a relatively high EMPS. This was to be expected, given that protozoal concentrations may vary simultaneously with other parameters such as nutrient availability, $\mathrm{pH}$ and rumen dilution rates. In addition, a study of protozoal concentrations alone can be misleading as species vary markedly in biological mass $(\sim 100$-fold in some cases; Dehority 1993) and, thus, in their potential effect on EMPS.

Values for supporting measures of rumen function are of interest quantitatively in their own right, in addition to any possible relationships with EMPS. For instance, rumen $\mathrm{pH}$ tended to be lower for legume-based diets and there were several observations for $\mathrm{pH}$ values $<6$, a value usually associated with subacute rumen acidosis. Total VFA concentration for cattle grazing all tropical grass pastures, and particularly the early and mid-wet pastures, was lower than for tropical legumes and ryegrass, but there were no large differences in molar proportions. The biggest difference was in the molar proportion of BCFA, which reflected the higher $\mathrm{CP}$ concentration and degradation of legumes and ryegrass. There was a linear relationship between FOR of $\mathrm{Yb}$ and FOR of CrEDTA, as expected.

In conclusion, EMPS in steers consuming tropical grass pastures was low $(<130 \mathrm{~g} \mathrm{MCP} / \mathrm{kg}$ DOMI $)$ and limited by RDP supply. Tropical legumes had adequate RDP supply (>130 g RDP $/ \mathrm{kg}$ DOMI) and resulted in EMPS in grazing steers within the expected range outlined in the feedings standards (130-170 g MCP/kg DOMI). Temperate grass, i.e. $\mathrm{RG}$, resulted in a very high EMPS of $>170 \mathrm{~g} \mathrm{MCP} / \mathrm{kg}$ DOMI, which was associated with a very high ratio of RDP/DOMI. In addressing low EMPS, the first priority is to ensure adequate RDP supply to meet microbial requirements for growth, in agreement with the first principles of all international feeding standards. However, high EMPS ( $\sim 170 \mathrm{~g} \mathrm{MCP} / \mathrm{kg}$ DOMI) appears to occur under situations of very high and excessive RDP/DOMI for unknown reasons. Increasing EMPS from tropical pastures is important as MCP provides most of the metabolisable protein supplied to the animal and, so, has a significant effect on the growth rate of the grazing animal.

\section{Acknowledgements}

This study was mainly funded by the Department of Agriculture and Fisheries (DAF), Queensland, who provided post-graduate support for M. K. Bowen. M. K. Bowen was also in receipt of an Australian Government Postgraduate Research Award. We are grateful to the former Health and Nutritional Biochemistry Laboratory of DAF, Michael Nielsen of the University of Queensland, and Ron Hendricksen and Carlo Gazzola of DAF, for conducting laboratory analyses. The technical support of Jim Kidd, Kieren McCosker, Antonio de Vega and the staff of Brian Pastures Research Station, Gayndah, are acknowledged. We have also benefited from David Reid's advice in improving the manuscript.

\section{References}

AFRC (Agricultural and Food Research Council) (1993) 'Energy and protein requirements of ruminants. An advisory manual prepared by the AFRC Technical Committee on Responses to Nutrients.' (CAB International: Wallingford, UK)

Baker SK, Dijkstra J (1999) Dynamic aspects of the microbial ecosystem of the reticulo-rumen. In 'Nutritional ecology of herbivores. Proceedings of the Vth international symposium on the nutrition of herbivores'. (Eds H-JG Jung, GC Fahey) pp. 261-311. (American Society of Animal Science: Savoy, IL)

Balcells J, Guada JA, Pieró JM, Parker DS (1992) Simultaneous determination of allantoin and oxypurines in biological fluids by high-performance liquid chromatography. Journal of Chromatography. A 575, 153-157. doi:10.1016/0378-4347(92)80517-T

Beever DE, Terry RA, Cammell SB, Wallace AS (1978) The digestion of spring and autumn harvested perennial ryegrass by sheep. Journal of Agricultural Science, Cambridge 90, 463-470. doi:10.1017/S002185 9600055970

Beever DE, Dhanoa MS, Losada HR, Evans RT, Cammell SB, France J(1986) The effect of forage species and stage of harvest on the processes of digestion occurring in the rumen of cattle. British Journal of Nutrition 56, 439-454. doi:10.1079/BJN19860124 
Bolam MJ (1998) Manipulation of the supply of protein and energy to ruminants consuming tropical forage through supplementation strategies. PhD Thesis, The University of Queensland, St Lucia, Brisbane.

Bolleter WT, Bushman CJ, Tidwell PW (1961) Spectrophotometric determination of ammonia as indophenol. Analytical Chemistry 33, 592-594. doi:10.1021/ac60172a034

Bowen MK, McLennan SR, Poppi DP (2001) Rumen fluid dilution rates in cattle grazing tropical pastures. Journal of Animal Science 78(Suppl. 1), 423.

Bowen MK, McCosker K, McLennan SR, Poppi DP (2003) The development of a novel method to estimate microbial protein production in grazing Brahman crossbred cattle. Tropical and Subtropical Agroecosystems 3, 365-367.

Bowen MK, Poppi DP, McLennan SR, Doogan VJ (2006) A comparison of the excretion rate of endogenous purine derivatives in the urine of Bos indicus and Bos taurus steers. Australian Journal of Agricultural Research 57, 173-177. doi:10.1071/AR05182

Bowen MK, Kidd JF, McLennan SR, Poppi DP (2008a) Protozoal concentrations in the rumen of cattle grazing tropical pastures. Proceedings of the Australian Society of Animal Production 27, 98.

Bowen MK, Poppi DP, McLennan SR (2008b) Ruminal protein degradability of a range of tropical pastures. Australian Journal of Experimental Agriculture 48, 806-810. doi:10.1071/EA07414

Bowen MK, Poppi DP, McLennan SR (2009) Recovery of intravenously infused chromium EDTA and lithium sulphate in the urine of cattle and their use as markers to measure urine volume. Animal 3, 548-556. doi: $10.1017 / \mathrm{S} 1751731108003765$

Bowen MK, Poppi DP, McLennan SR (2010a) Rumen degradability of tropical pasture leaf in cattle grazing different pasture types. Proceedings of the Australian Society of Animal Production 28, 55.

Bowen MK, Poppi DP, McLennan SR (2010b) Rumen degradability of a tropical grass hay in cattle grazing different pasture types. Proceedings of the Australian Society of Animal Production 28, 57.

Broderick GA (1994) Quantifying forage protein quality. In 'National conference on forage quality, evaluation, and utilization'. (Eds GC Fahey, M Collins, DR Mertens, LE Moser) pp. 200-228. (University of Nebraska: Lincoln, WI)

Chen XB, Gomes MJ (1995) 'Estimation of microbial protein supply to sheep and cattle based on urinary excretion of purine derivatives: an overview of the technical details.' (International Feed Resources Unit, Rowett Research Institute: Aberdeen, UK)

Corbett JL (1976) Nutritional aspects of the growth of grazing animals. Proceedings of the Australian Society of Animal Production 11, 281-288.

Corbett JL, Pickering FS (1983) Rumen microbial degradation and synthesis of protein in grazing sheep. In 'Feed information and animal production'. (Eds GE Robards, RG Packham) pp. 301-302. (CABI: Farnham Royal, UK)

Cruickshank GJ, Poppi DP, Sykes AR (1992) The intake, digestion and protein degradation of grazed herbage by early-weaned lambs. British Journal of Nutrition 68, 349-364. doi:10.1079/BJN19920094

CSIRO (2007) 'Nutrient requirements of domesticated ruminants.' (Eds M Freer, H Dove, J Nolan) (CSIRO Publishing: Melbourne)

de Vega A, Poppi DP (1997) Extent of digestion and rumen conditions as factors affecting passage of liquid and digesta particles in sheep. The Journal of Agricultural Science 128, 207-215. doi:10.1017/ S0021859696004078

Dehority BA (1993) 'Laboratory manual for classification and morphology of rumen ciliate protozoa.' (CRC Press: Boca Raton, FL)

Detmann E, Valente EEL, Batista ED, Huhtanen P (2014) An evaluation of the performance and efficiency of nitrogen utilization in cattle fed tropical grass pastures with supplementation. Livestock Science 162, 141-153. doi:10.1016/j.livsci.2014.01.029
Dewhurst RJ, Davies DR, Merry RJ (2000) Review article. Microbial protein supply from the rumen. Animal Feed Science and Technology 85, 1-21. doi:10.1016/S0377-8401(00)00139-5

Djouvinov DS, Todorov NA (1994) Influence of dry matter intake and passage rate on microbial protein synthesis in the rumen of sheep and its estimation by cannulation and a non-invasive method. Animal Feed Science and Technology 48, 289-304. doi:10.1016/0377-8401(94) 90179-1

Dove H (1992) Using the n-alkanes of plant cuticular wax to estimate the species composition of herbage mixtures. Australian Journal of Agricultural Research 43, 1711-1724. doi:10.1071/AR9921711

Dove H, Mayes RW (1991) The use of plant wax alkanes as marker substances in studies of the nutrition of herbivores: a review. Australian Journal of Agricultural Research 42, 913-952. doi:10.1071/AR9910913

Dove H, Milne JA (1994) Digesta flow and rumen microbial protein production in ewes grazing perennial ryegrass. Australian Journal of Agricultural Research 45, 1229-1245. doi:10.1071/AR9941229

Dowling RM, McKenzie RA (1993) 'Poisonous plants. A field guide.' (Queensland Government: Brisbane)

Faichney GJ, Welch RJ, Brown GH (1995) Prediction of the excretion of allantoin and total purine derivatives by sheep from the 'creatinine coefficient'. Journal of Agricultural Science, Cambridge 125, 425-428. doi:10.1017/S0021859600084938

Foss Tecator (2002a) 'Application sub-note ASN 3805. The determination of neutral detergent fibre using the fibercap system.' (Foss Tecator: Hoganas, Sweden)

Foss Tecator (2002b) 'Application sub-note ASN 3804. The determination of acid detergent fibre using the fibercap system.' (Foss Tecator: Hoganas, Sweden)

Fulkerson WJ, Donaghy DJ (2001) Plant-soluble carbohydrate reserves and senescence: key criteria for developing an effective grazing management system for ryegrass-based pastures: a review. Australian Journal of Experimental Agriculture 41, 261-275. doi:10.1071/EA00062

Galyean ML, Krysl LJ, Estell RE (1986) Marker-based approaches for estimation of fecal output and digestibility in ruminants. In 'Feed intake of beef cattle symposium. Miscellaneous publication 121'. (Ed. FN Owens) pp. 96-113. (Oklahoma State University: Stillwater, OK)

Hume ID (1970) Synthesis of microbial protein in the rumen. II. A response to higher volatile fatty acids. Australian Journal of Agricultural Research 21, 297-304. doi:10.1071/AR9700297

Hume ID, Purser DB (1974) Ruminal and post-ruminal protein digestion in sheep fed on subterranean clover harvested at four stages of maturity. Australian Journal of Agricultural Research 26, 199-208. doi:10.1071/ AR9750199

Kennedy PM (1982) Ruminal and intestinal digestion in Brahman crossbred and Hereford cattle fed alfalfa or tropical pasture hay. Journal of Animal Science 55, 1190-1199.

Lee MRF, Harris LJ, Moorby JM, Humphreys MO, Theodorou MK, MacRae JC, Scollan ND (2002) Rumen metabolism and nitrogen flow to the small intestine in steers offered Lolium perenne containing different levels of water-soluble carbohydrate. Animal Science 74, 587-596.

McLeod MN, Minson DJ (1978) The accuracy of the pepsin-cellulase technique for estimation the dry matter digestibility in vivo of grasses and legumes. Animal Feed Science and Technology 3, 277-287. doi:10.1016/0377-8401(78)90002-0

McLeod MN, Minson DJ (1980) A note on Onozuka 3S cellulase as a replacement for Onuzuka SS (P1500) cellulase when estimating forage digestibility in vitro. Animal Feed Science and Technology 5, 347-350. doi:10.1016/0377-8401(80)90022-X

Minson DJ, McLeod MN (1972) 'The in vitro technique: its modification for estimating digestibility of large numbers of tropical pasture samples. Technical paper no. 8.' (CSIRO Division of Tropical Pastures: Melbourne) 
Mullik ML (1999) Strategies to increase efficiency of microbial protein synthesis and productivity of cattle on a tropical pasture. $\mathrm{PhD}$ Thesis, The University of Queensland, St Lucia, Brisbane.

NRC (National Research Council) (2000) 'Nutrient requirements of beef cattle.' Seventh revised edn. (National Academy Press: Washington, DC)

Nsahlai IV, Osuji PO, Umunna NN (2000) Effect of form and of quality of feed on the concentrations of purine derivatives in urinary spot samples, daily microbial N supply and predictability of intake. Animal Feed Science and Technology 85, 223-238. doi:10.1016/S0377-8401(00) 00138-3

Panjaitan T, Quigley SP, McLennan SR, Swain T, Poppi DP (2010) Intake, retention time in the rumen and microbial protein production of Bos indicus steers consuming grasses varying in crude protein content. Animal Production Science 50, 444-448. doi:10.1071/AN09197

Panjaitan T, Quigley SP, McLennan SR, Swain AJ, Poppi DP (2015) Spirulina (Spirulina platensis) algae supplementation increases microbial protein production and feed intake and decreases retention time of digesta in the rumen of cattle. Animal Production Science 55, 535-543. doi:10.1071/ AN13146

Poppi DP, McLennan SR, Bediye S, de Vega A, Zorrilla-Rios J (1997) Forage quality: strategies for increasing nutritive value of forages. In 'Proceedings of the 18th international grassland congress'. Winnepeg, Manitoba, Canada, pp. 307-322.

Prior SJ, Poppi DP, McLennan SR (1998) Microbial protein production in cattle fed ryegrass, buffel grass and spear grass hays. Animal Production in Australia 22, 315.

Satter LD, Slyter LL (1974) Effect of ammonia concentration on rumen microbial protein production in vitro. British Journal of Nutrition 32, 199-208. doi:10.1079/BJN19740073

Shem MN, Hovell FDD, Kimambo AE (1999) Estimation of net ruminal protein synthesis from urinary allantoin excretion by bulls given tropical feeds. Animal Feed Science and Technology 81, 279-289. doi:10.1016/ S0377-8401(99)00088-7

Siddons RC, Paradine J, Beever DE, Cornell PR (1985) Ytterbium acetate as a particulate-phase digesta-flow marker. British Journal of Nutrition 54, 509-519. doi:10.1079/BJN19850136
Stobbs TH (1975) Factors limiting the nutritional value of grazed tropical pasture for beef and milk production. Tropical Grasslands 9, 141-150.

Stouthamer AH, Bettenhaussen C (1973) Utilization of energy for growth and maintenance in continuous and batch cultures of microorganisms. A reevaluation of the method for the determination of ATP production by measuring molar growth yields. Biochimica et Biophysica Acta 301, 53-70. doi:10.1016/0304-4173(73)90012-8

Sweeney RA (1989) Generic combustion method for determination of crude protein in feeds. Journal - Association of Official Analytical Chemists 72, 770-774.

Thomson BC, Cruickshank GJ, Poppi DP, Sykes AR (1985) Diurnal patterns of rumen fill in grazing sheep. Proceedings of the New Zealand Society of Animal Production 45, 117-120.

Tilley JMA, Terry RA (1963) A two-stage technique for the in vitro digestion of forage crops. Journal of the British Grassland Society 18, 104-111. doi:10.1111/j.1365-2494.1963.tb00335.x

Tothill JC, Hargreaves JNG, Jones RM, McDonald CK (1992). 'BOTANAL: a comprehensive sampling technique for estimating pasture yield and composition. 1. Field sampling. Tropical agronomy technical memorandum no. 78.' (CSIRO Division of Tropical Crops and Pastures: Brisbane)

Tuyen DV, Tolosa XM, Poppi DP, McLennan SR (2015) Effect of varying the proportion of molasses in the diet on intake, digestion and microbial protein production by steers. Animal Production Science 55, 17-26. doi:10.1071/AN13225

Valaderes Filho SC, dos Santos Pina D, Chizotti ML, Ferreira Diniz Valaderes R (2010) Ruminal feed protein degradation and microbial protein synthesis. In 'Nutrient requirements of zebu beef cattle BR-Corte'. 2nd edn. (Eds S De Campos Valadares Filho, M Inacio Marcondes, M Chizzotti, P Veiga Rodrigues Paulino) pp. 13-44. (Federal University of Vicosa, Department of Animal Science: Vicosa, Brazil)

Weier KL, Wilson JR, White RJ (1977) 'A semi-automated procedure for estimating total non-structural carbohydrates in grasses, and comparison with two other procedures. Technical paper no. 20.' (CSIRO Division of Tropical Crops and Pastures: Melbourne) 